UDC 338.485:332.1(477)=111

\title{
FOREIGN EXPERIENCE TO IMPROVE THE COMPETITIVENESS OF REGIONS IN ACCORDANCE WITH THE DEVELOPMENT OF THE TRAVEL AND HOTEL RESTAURANT INDUSTRY
}

DOI 10.30838/ P.ES.2224.230419.60.474

\section{Osipenko K., PhD in Economics \\ Mariupol State University, Mariupol}

The foreign experience of increasing the competitiveness of regions through the development of tourism and hotel and restaurant industry has been analyzed in this article. It has been determined that certain competitive advantages inherent to each region become important, which, if successfully used and effective combination, can ensure the priority of its development in a competitive environment. In this context, tourism and hotel and restaurant industries, which are among the most profitable sectors of the world economy, are becoming increasingly important for the development of the economy and the social sphere of the region. It has been outlined that taking into account certain competitive advantages that are inherent to each region, their successful use and effective combination are important, which allows to ensure the priority of regional development in a competitive environment. Accordingly, the tourist and hotel-restaurant industry are among the most lucrative sectors of the world economy and are becoming more and more important for the development of the economy and the social sphere of the region. It was determined that it is precisely because of the active and successful advancement of these sectors in the market that it is possible to increase the competitiveness of the regions of the country, to increase their socio-economic development. It is stated that it is precisely because of the active and successful advancement of these industries in the market that it is possible to increase the competitiveness of the regions of the state, to increase their socio-economic development. Thus, the purpose of the scientific floor is to deepen the theoretical foundations for the development of the competitiveness of the regions at the present stage and to develop recommendations on the enhancement of the role of the hotel and restaurant economy in its enhancement. In the article, the author paid attention to the analysis and development of the directions of hotel industry development in the regions of Ukraine through the development of tourism and hotel and restaurant industry. Deeper and more precise theoretical positions regarding the development of the competitiveness of the region. Recommendations for strengthening the role of the hotel and restaurant industry are systematized.

Keywords: tourism; regional tourism; regional competitiveness; hotel and restaurant industry; international tourism

(C) Осипенко К.В., к.е.н., 2019 
УДК 338.485:332.1(477)=111

ЗАРУБІЖНИЙ ДОСВІД ПІДВИЩЕННЯ

КОНКУ РЕНТОСПРОМОЖНОСТІ РЕГІОНІВ ЗА РАХУНОК

РОЗВИТКУ ТУРИСТИЧНОЇ Й ГОТЕЛЬНО-РЕСТОРАННОЇ ГАЛУЗІ

DOI 10.30838/ P.ES.2224.230419.60.474

Осипенко К. В., к.е.н.

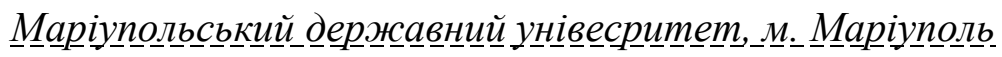

У статті проаналізовано зарубіжний досвід підвищення конкурентоспроможності регіонів за рахунок розвитку туристичної й готельно-ресторанної галузі. Визначено, що важливого значення набувають властиві кожному регіону певні конкурентні переваги, які при вдалому використанні й ефективній комбінації можуть забезпечувати пріоритет його розвитку в умовах конкуренції. В цьому контексті, одним 3 ключових векторів розвитку економіки та соціальної сфери регіону стає туристична та готельно-ресторанна галузі, які $\epsilon$ одними 3 високорентабельних галузей світової економіки. Окреслено, що враховуючи певні конкурентні переваги, які притаманні кожному регіону, важливого значення набуває ї успішне використання та ефективне поєднання, що дозволяє забезпечити пріоритет регіонального розвитку в конкурентному середовищі. Відповідно туристична та готельно-ресторанна індустрія є одними 3 найбільш прибуткових галузей світової економіки та стають все більш важливими для розвитку економіки та соціальної сфери регіону. Було визначено, що саме через активне та успішне просування цих галузей на ринку можна посилити конкурентоспроможність регіонів країни, підвищити рівень їх соціальноекономічного розвитку. Окреслено, що саме завдяки активному та успішному просуванню цих галузей на ринку можливо посилити конкурентоспроможність регіонів держави, підвищити рівень їх соціально-економічного розвитку. Від так, мета наукової статі полягає у поглибленні теоретичних основ розвитку конкурентоспроможності регіонів на сучасному етапі та в розробці рекомендацій щодо активізації ролі готельно-ресторанного господарства у іiі підвищенні. У статті, автором було приділено увагу аналізу та розробці напрямів розвитку готельного господарства в регіонах України через розвиток туристичної та готельно-ресторанної індустрії. Поглиблено та уточнено теоретичні позиції щодо розвитку конкурентоспроможності регіону. Систематизовано рекомендації щодо посилення ролі готельної та ресторанної індустрії.

Ключові слова: туризм; регіональний туризм; регіональна конкурентоспроможність; готельно-ресторанна галузь; міжнародний туризм

Problem statement. Tourism, through the formation of regional, entities opens up great opportunities for the socio-economic development of territories (countries, regions, cities) that have different amounts of tourist resources. Due 
to tourism in many industries and areas of activity involved in the formation of tourism or tourism related products, it is possible to receive a basic or additional income. Tourism can be developed in any country, region, the main thing - you need to have a good idea of its specific features and relevant information provision in the planning of activities. Tourism should be regarded as an open socio-economic system, which is influenced by many factors. Many enterprises are either directly or indirectly involved in the tourism industry, the activities of each, as a rule, depend on the activities of each participant in the system.

Analysis of recent research and publications. A large number of works of domestic and foreign scientists is devoted to the study of competitiveness issues in the region, such as: S. Zapototsky, B. Gubsky, B. Bezugla, O. Burdiak, Y. Anthonii, P. Belenkyi, D. Stechenko, F. Fathutdynov, L. Cherniuk, N. Kaliuzhnova, B. Klymchuk, etc. The works of the following scholars are devoted to problems of the development of the sphere of tourism and hotel and restaurant economy were given attention in the work: Preieger D., Maliarchuk I., Tkachenko T., Munin G., Baranovskii V., Borodin V. and many others. However, despite the abundance of research, the issue of the development of the hotel and restaurant industry as a component of the competitiveness of the region requires further research.

Statement of objectives. The purpose of the scientific article is to deepen the theoretical foundations for the development of the competitiveness of the regions at the present stage and to elaborate recommendations on enhancing the role of the hotel and restaurant economy in its enhancement.

Outline of main results. The main purpose of the state policy of regional development is to ensure the quality living conditions and welfare of the population of the regions, minimizing the disproportionality of the development of the regions. Herewith certain competitive advantages peculiar of each region acquire great importance, as when used successfully and efficiently, can ensure the priority of its development in a competitive environment. Therefore, it is reasonable to systematize foreign experience on increasing the competitiveness of the regions of the countries, particularly through an increase in the share of industries in the non-productive sphere (tourist and hotel-restaurant economy) and the possibility of its implementation in Ukrainian reality. The problem of increasing the competitiveness of territories that are not able to solve their own socioeconomic problems independently or realize their high potential and need active support from the 
state, i.e. problem regions, is of particularly relevance. Several types of problem regions are distinguished: underdeveloped, depressed, critical, oldfashioned and border-straddling regions. Economic problems of the old industrial areas are associated with the characteristic features of the territory, which include as follows [6]:

- practically full engagement in the economic circulation of natural resources;

- high population density; the predominance of the branches of industry that originated during the industrial revolution;

- excessive level of production concentration;

- physically and morally outdated productive and social infrastructure;

- high density of outdated, environment polluting enterprises;

- crisis phenomena in economics, politics, ecology.

The competitiveness of the old industrial regions of Ukraine may be increased upon the restructuring of their economy, that is, the development of traditional and expansion of new types of economic activity, which will ensure long-term, sustainable and efficient socio-economic development of the territories. The main purpose of diversification is the effective socio-economic development of the region through stimulating the development of alternative sectors of the economy. Taking into account the need to diversify the economy of the old industrial regions, we suggest paying attention to the development of the tourism industry and to analyze the experience of foreign countries $[3,4,5]$ with regard to its revitalization and its role in addressing problem areas (table 1).

Summarizing the experience of restructuring the economy of individual cities around the world, wherein the development of tourism has been the main driver of economic growth and the increase of the socio-economic level, one should mind that the implementation of the above-mentioned projects has several factors in common:

- predominance of infrastructure projects;

- integrated investment planning;

- Combination of the efforts of the public, enterprises, state, regional and municipal authorities within the framework of specially established new institutions - territorial development corporations.

Therefore, in order to increase competitiveness of the problem regions of Ukraine tourism has to be developed. It should be noted that tourism potential occupies a prominent place in the system of economic potential of the state and 
its development significantly influences the increase of the general level of competitiveness of the region. In order to provide tourist activity of regions, in addition to the main resources (natural and recreational, historical and cultural), the presence of a developed socio-economic infrastructure, namely transport, hotel, food, information, etc., is needed.

The assumption concerning the weak development of tourist infrastructure in the old industrial regions of Ukraine is based on statistical data of official sources and is confirmed by the data of various scientific researches.

Table 1 - Results of economy diversification of troubled cities through activation of the tourist sphere: foreign experience

\begin{tabular}{|c|c|c|}
\hline $\begin{array}{l}\text { City name } \\
\text { /Leading branch of } \\
\text { economy }\end{array}$ & $\begin{array}{l}\text { Directions } \\
\text { diversification } \\
\text { city economy }\end{array}$ & Results of diversification \\
\hline $\begin{array}{l}\text { Pullman } \\
\text { (USA) } \\
\text { Machine-building }\end{array}$ & Tourism center & $\begin{array}{l}\text { The US Supreme Court decision on adding } \\
\text { Pullman to the city of Chicago district; State } \\
\text { recognition of the historical object of protection } \\
\text { of Pullman on the scale of the city, state and } \\
\text { country due to the active social position of locals. }\end{array}$ \\
\hline $\begin{array}{l}\text { Saltville } \\
\text { (USA) } \\
\text { Chemical Industry }\end{array}$ & $\begin{array}{l}\text { Travel and business } \\
\text { center }\end{array}$ & $\begin{array}{l}\text { Agency for the protection of the environment of } \\
\text { the United States took measures to improve the } \\
\text { environmental situation in the city. Active } \\
\text { development of the small (family) business: the } \\
\text { introduction of a large set of benefits, consulting } \\
\text { support, etc. }\end{array}$ \\
\hline $\begin{array}{l}\text { Big Stone Gap } \\
\text { (USA) } \\
\text { Coal industry }\end{array}$ & $\begin{array}{l}\text { Use of ecotourism } \\
\text { for attracting new } \\
\text { investments and job } \\
\text { creation through } \\
\text { support from local } \\
\text { entrepreneurs }\end{array}$ & $\begin{array}{l}\text { Creation of local infrastructure: local college } \\
\text { (special workshops for entrepreneurs), small } \\
\text { business development center, local development } \\
\text { lending institution (special loans for local } \\
\text { businessmen involved in ecotourism: kayaking, } \\
\text { rafting, cycling, camping, and the } \\
\text { BedandBreakfast industry). The city has been } \\
\text { successfully remodelled into the center of } \\
\text { ecotourism. }\end{array}$ \\
\hline $\begin{array}{l}\text { CardiffBay } \\
\text { (United Kingdom) } \\
\text { Coal industry }\end{array}$ & $\begin{array}{lr}\begin{array}{l}\text { Development } \\
\text { tourism }\end{array} \\
\text { entertainment } \\
\text { industries. }\end{array}$ & $\begin{array}{l}\text { Diversification of the city's economy by means of } \\
\text { public-private partnership mechanisms (creation } \\
\text { and functioning of "urban development } \\
\text { corporations") in the direction of development of } \\
\text { tourism and hotel and restaurant enterprises. }\end{array}$ \\
\hline
\end{tabular}

Source: $[3,4,5]$

The tourist business is a profitable type of investment, since it gives a direct and high-speed economic effect (payback is 2-4 years, the cost of creating one workplace is 20 times lower than in industry) [1, p. 74].

In view of the above, the use of a cluster system becomes especially relevant, that is, an association of interconnected enterprises and organizations the activities of which are aimed at providing tourist services, which will enable the development of this industry in the region's economy. A tourist cluster 
should unite: travel agencies and firms; enterprises of hotel and restaurant industry, public catering; educational institutions providing training for specialists in the tourism industry as well as hotel and restaurant industry; organizations and institutions providing information, legal, scientific and methodological support. The main purpose of the activity of tourist clusters is to develop the competitive advantages of the region by promoting all types of tourism, which envisages resolution of the following priority tasks [2]:

- to establish a real tourist infrastructure inventory (available / required), so that investors know what to invest in;

- to advertise, creating a tourist image of the region;

- to create the information basis of the region with the definition of possible tourist routes, recreation places, transport system, etc. through the creation of an Internet web-site, printed publications and information tourist offices, bureaus, centers.

- to raise the level of skills and intellectual potential of tourism workers;

- to develop the entertainment industry inclusive of local peculiarities;

- to carry out measures on preservation and reconstruction of landmarks of historical importance;

- to receive more funding for the development of all types of tourism from local and state budgets, international funds. The economic mechanism of the interconnection of the cluster participants can be carried out in the following variants.

The first typical pattern of the tourist cluster displays that tourism business enterprises can develop chaotic relations. Depending on the need, they conclude cooperation agreements with each other. The second pattern of the tourist cluster as a separate structure, formed by participants in the tourism business includes two components. First, it is the creation of an initiative group forming a tourist cluster, which should include representatives of key enterprises (usually powerful tour operator firms). Secondly, other enterprises of the tourist business (establishments for accommodation and improvement of tourists, transportation companies, etc.) are involved in cooperation.

A distinctive feature of such a cluster is that its employees have two executives who have equal rights at the same time. Consequently, there is a system of double submission. On the one hand, it is the head of a tourism business enterprise (hotel, restaurant, etc.) and, on the other hand, the head of the cluster. At the same time, employees can perform both the current tasks directly to the parent company and the cluster's tasks, and their income is 
formed in the form of wages accrued at the main place of work. The sources of funding for cluster projects are the funds of enterprises - its participants.

The factors creating such models of the tourist cluster, apart from the territorial ones, are the factor of economic unity and resource sharing, the factor of location, competition and cooperation.

The third pattern of the tourist cluster as a separate entity is the one formed by an independent entity. This pattern has significant differences in the economic mechanism of the relationship between its participants. So, the initiative group forming the tourist cluster is represented by independent experts who are not directly related to the tourism business, but have experience in implementing the cluster model in other regions or industries (for example, experts from regional development agencies, experts from a variety of programs and initiatives). They, forming a tourist cluster with their own material base, personnel, etc., establish links with tourism business enterprises and conclude relevant cooperation agreements with the latter.

The sources of funding for projects of such a tourist cluster are the means of pre-defined enterprises of the tourist industry, as well as other sources that can generate income related to the statutory activities of the cluster. Revenues of the tourist cluster employees are formed in the form of wages.

The fourth pattern of the tourist cluster as a separate structure, is formed by the state authority. The initiative element of this pattern is the department of culture and tourism of the oblast, which forms a separate non-profit subdivision, acting on its behalf, but has its own charter, property, tasks, etc. In this case, the department of culture and tourism continues to perform its direct functions in the regulation, control, statistical accounting, etc. in the field of tourism.

In this pattern of the tourist cluster a system of double submission comes up once again. On the one hand, it is the head of the department, and on the other hand, the head of the cluster. The tourist cluster staff can also perform tasks within the framework of the responsibilities defined by the culture and tourism department and the cluster's tasks.

Sources of financing in such a cluster pattern may be: local budget funds, investments of enterprises and organizations, grants of international organizations, as well as funds of enterprises participating in the cluster.

It should be noted that according to O. Kolesnik [2], in modern conditions of Ukraine such pattern is the best possible. It is the state that has to assume 
the role of the initiator and unite enterprises of the tourism industry, which will enable to realize the tasks set forth above effectively and to the fullest.

Conclusion. Thus, the development of the tourism sector, hotel and restaurant industry, in particular, should be the driving force behind the transformation of the economy of the troubled regions of the country, through the creation of new workplaces and a general increase in the volume of services provided. Implementation of measures for the development of tourism infrastructure, respectively, will increase the share of the intangible sector in the economy of the region; improvement of the environment, owing to the environmentally sound activity of the industry; the development of the communication infrastructure of the region, and, ultimately, an increase in the welfare of the population, that is, the realization of the main goal of the regional policy of the country.

\section{СПИСОК ВИКОРИСТАНИХ ДЖЕРЕЛ:}

1. Дубенюк Я.А. Розвиток світового ринку туристичних послуг: [монографія] / Я.А. Дубенюк. - Донецк: «Вебер», 2009. - 184c.

2. Колесник О.О. Кластерна модель розвитку туризму в Україні / О.О.Колесник // Економіка. Управління. Інновації. - 2009. - №1 .

3. Коновалова Т. А. Государственные механизмы повышения эффективности развития монопромышленных городов стратегического значения / Т.А. Коновалова // Молодой ученый. - 2013. - №3. - С. 229-234.

4. Пьянкова С.Г. Формирование институтов развития моно профильных территорий: зарубежный и отечественный опыт / С.Г. Пьянкова // Экономические науки: фундаментальные исследования. - 2011. - № 12. - С. 422-427

5. Рудова А.А. Повышение занятости в моногородах: отечественный и зарубежный опыт [Электронный ресурс] / А.А. Рудова // Проблемы месного самоуправления. Режим доступа: http://www.samoupravlenie.ru/50-02.php

6. Туризм як національний пріоритет : кол. монографія / за ред. І. М. Писаревського. Харків : ХНАМГ, 2010. - 284 с.;

7. Черниченко Г.А. Региональная экономика: [учебное пособие] / Г.А. Черниченко, О.А. Чижикова, К.С. Митюшкина. - Мариуполь: МГУ, 2010. - 173 с.

8. Шмагіна Ю.В. Перспективи розвитку готельного бізнесу та ресторанної справи / Ю.В. Шмагіна [Електронний ресурс]. - Режим доступу: http://www.rusnauka.com/2_KAND_2009/Economics/39523.doc.htm 


\section{REFERENCES:}

1. Dubenyuk Ya.A. (2009). Rozvytok svitovogo rynku turistichnykh poslug. Donetsk: «Veber» [in Ukrainian].

2. Kolesnik O.O. (2009). Klasterna model rozvitku turizmu v Ukraini. Ekonomika. Upravlinnya. Innovatsii, №1. Retrieved from http://tourlib.net/statti_ukr/kolesnyk.htm [in Ukrainian].

3. Konovalova T. A. (2013). Gosudarstvennyie mehanizmi povysheniia effektivnosti razvitiia monopromyishlennyih gorodov strategicheskogo znacheniia. Molodoy uchenyiy, 3, 229234 [in Russian].

4. Pyankova S.G. (2011). Formirovanie institutov razvitiia mono profilnyih territoriy: zarubezhnyiy i otechestvennyiy opyit. Ekonomicheskie nauki: fundamentalnyie issledovaniya, 12, 422-427 [in Ukrainian].

5. Rudova A.A. Povyishenie zanyatosti v monogorodah: otechestvennyiy i zarubezhnyiy opyt. Problemy mesnogo samoupravleniya. Retrieved from: http://www.samoupravlenie.ru/ 50-02.php

6. I. M. Pisarevskiy. (2010) Turyzm yak nacionalnyj priorytet. Xarkiv : XNAMG [in Ukrainian].

7. Chernichenko G.A., Chizhikova O.A., Mityushkina K.S. (2010). Regionalnaya ekonomika.- Mariupol: MGU [in Ukrainian].

8. ShmagIna Yu.V. Perspektivi rozvitku gotelnogo biznesu ta restorannoyi spravi. Retrieved from: http://www.rusnauka.com/2_KAND_2009/Economics/39523.d [in Ukrainian]. 